\title{
Determination of Optimum Levels of Occupational Health and Safety in a Setting with Informal and Formal Sectors
}

\author{
Dincer Dedeoglu, Caglar Yurtseven \\ Department of Economics, Bahcesehir University, Istanbul, Turkey \\ Email: cayurtseven@yahoo.com
}

Accepted 21 February 2016; published 24 February 2016

Copyright (C) 2016 by authors and Scientific Research Publishing Inc.

This work is licensed under the Creative Commons Attribution International License (CC BY). http://creativecommons.org/licenses/by/4.0/

c) (i) Open Access

\begin{abstract}
In this paper, we aim to understand the determination of the optimum levels of occupational health and safety in a setting where firms have the outside option of working in the informal sector. We construct a theoretical model in which equilibrium labor cost is exogenous and firms have an option to decide to work in the high efficiency formal or low cost informal sector, where there is a risk of detection and zero profit if they choose to work informally. Considering the existence of a large informal sector in many developing countries, the findings of this study are of great importance.
\end{abstract}

Keywords

Occupational Health and Safety, Economic Value of Life, Informal Sector, Developing Countries

\section{Introduction}

The informal sector includes a wide range of labor market activities. It comprises the coping behavior of individuals and families in an economic environment characterized by scarce earning activities and the rational behavior of entrepreneurs that desire to escape state regulations [1]. Coping strategies, or survival activities, include casual, temporary and unpaid jobs, subsistence agriculture, and multiple jobholding, whereas unofficial earning strategies include tax evasion, avoidance of labor regulation or other government or institutional regulations, no registration of the company, crime, and corruption activities not registered by statistical offices $[1]^{1}$. In brief, informal sector is the untaxed and unmonitored part of an economy by any form of authority. Activities of the informal economy are not included in the national income accounting [2]. On the other hand, the formal

${ }^{1}$ For further information please see http://www.worldbank.org.

How to cite this paper: Dedeoglu, D. and Yurtseven, C. (2016) Determination of Optimum Levels of Occupational Health and Safety in a Setting with Informal and Formal Sectors. Modern Economy, 7, 204-211.

http://dx.doi.org/10.4236/me.2016.72022 
sector is defined as the registered part of an economy within the purview of state monitoring and regulation [3].

The World Bank specifies the main role of the informal sector as creating jobs and reducing unemployment and underemployment. However, as is widely known, the created jobs are both low-paid and not secure. In this paper, we aim to determine the optimum levels of occupational safety costs by the government, considering the coexistence of informal and formal sectors. If we note the big share of the informal sector mainly in developing countries, this determination becomes even more important.

The informal sector had been of interest since the 1970s when it was formally defined in $1972 .{ }^{2}$ The informal sector does not operate in marginal production and services fields and is actually not independent from the formal sector [4]. This relationship is documented in various studies. Measuring the informal sector is of importance for policy and the ILO provides a general guideline for the measurement of the size of the informal sector. Figure 1 presents the share of employees employed in the informal sector in developing countries. It indicates that in developing countries the informal sector plays a key role in employment generation. It can be clearly seen that the share of employment generated by informal sector varies among countries. The size of the informal employment is greater in developing countries and among developing countries, it is relatively larger in Africa, South America and Asia [5] [6].

The main reasons pushing businesses into the informal sector are high social security contributions, minimum wage regulations, excessive labor market regulations, corruption, and poor governance [7]. It is apparent that the informal sector has problems with regard to occupational safety and health. The main occupational safety and health issues are the promotion of occupational safety and health, skill developing, social protection, employment creation, and providing long-lasting improvements in working and living conditions [8]. In particular, secure workplace environments is attracting the attention of both academic and political actors. Political parties promise more secure workplace environments, better health services and retirement conditions. However, the employer, directly, and employee, indirectly, bear the cost of these. If we consider the effect of these costs on the composition of the formal/informal sector, the determination of the optimal levels of costs gains key importance. In most developing countries, although the formal sector generates a larger share, the informal sector size is still quite large so that it is not possible not to take it into consideration while studying the effect of regulations on labor market [9] [10]. . $^{3}$

In this pioneering study, we solve for the optimal levels of these additional costs by considering the effect of them on firms' decisions to operate in the formal or informal sector. First, we provide a thorough survey of the literature. Next, after stating the assumptions of the paper, we present the model for the optimum levels of occupational health and safety. In the Results section, we discuss the findings of the theory with references to the real data. Finally, we briefly conclude.

\section{Literature Review}

In the literature, existence of formal and informal labor and firms is shown to depend on various factors, such as labor and product regulations, administrative complexity of taxation and related costs, and legal quality [11]. The formal sector abides by the labor market regulations and its access to social protection is more likely, accordingly it cannot avoid the costs of operating formally. It is also noted that productivity is higher in formal firms [12]. However, the informal sector does not comply with regulations. Therefore, they can avoid such costs and provision of formal insurance [11] [13]. The cost of informality is the punishment cost, which occurs due to detection (zero profit if detected). The probability of detection depends on numerous factors such as firm size ${ }^{4}$ or the share of informal firms in the market ${ }^{5}$ [11]. Therefore, for a firm, the transition to the informal sector depends on the costs and benefits of formality. Since occupational safety and health, security, minimum wage tax, registration costs etc. are among the costs of formality, determining the optimal level of these factors is of key importance.

In the literature, there are a number of studies examining these costs and their effects. Some firms may decide to stay informal even if the registration costs are moderate [14]. Burdensome regulations have a significant effect

\footnotetext{
${ }^{2}$ For the pioneering definition of informality please see ILO Kenya mission report.

${ }^{3}$ The informal sector is substantively heterogenous in sectors both across and between countries [9].

${ }^{4}$ Smaller, less productive, firms do not find formality desirable because they receive no benefit from access these formal institutions [18].

${ }^{5}$ If the share of informal firms is low in the industry then it does not attract considerable public attention, hence less government effort for detection.
} 


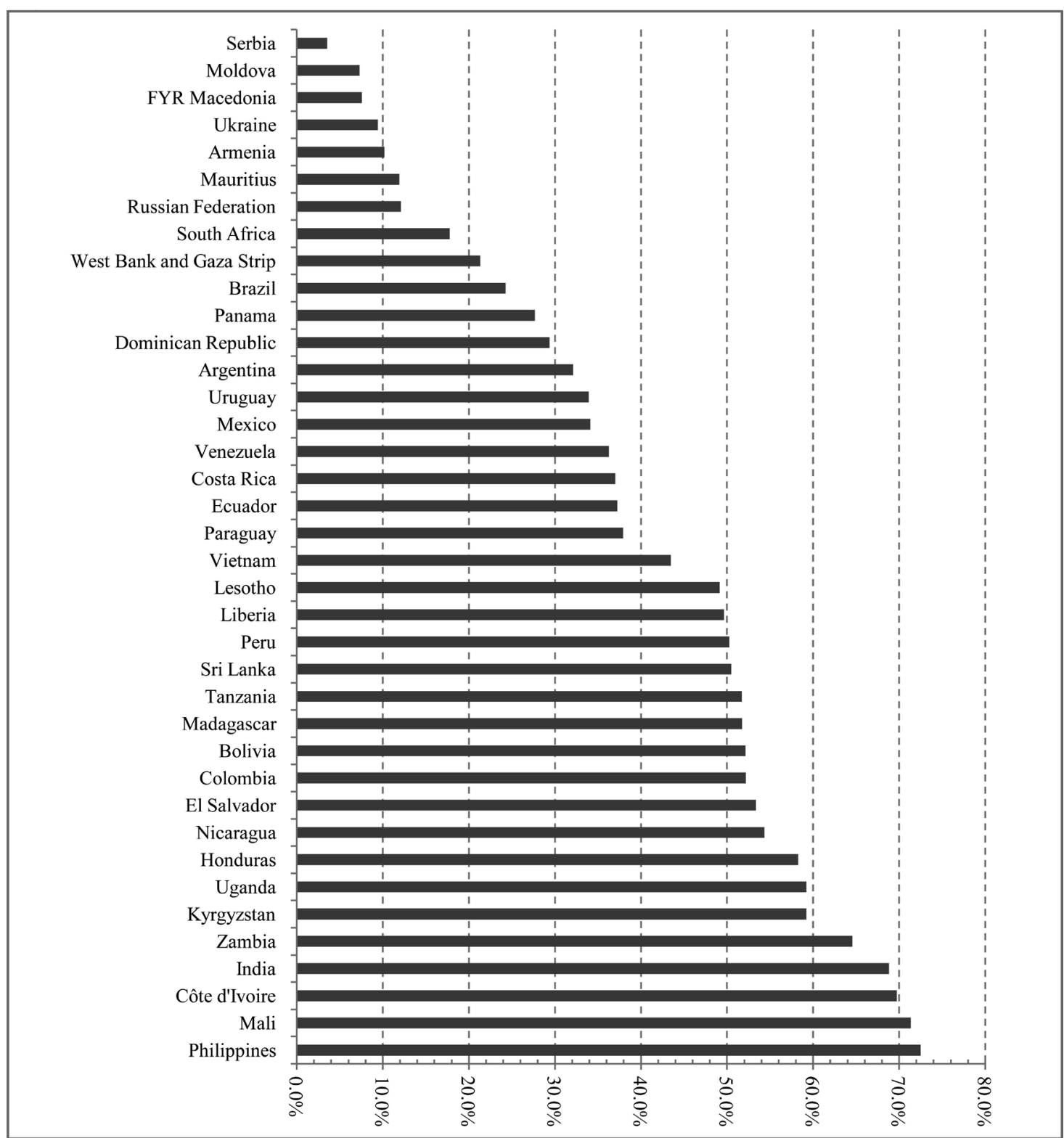

Source: ILO-Department of Statistics, Statistical update on employment in the informal economy (June 2012).

Figure 1. Share of persons employed in the informal sector.

on the size of the informal sector [15]. For example, following a number of regulatory reforms, a reduction in registration time positively affected the newly established formal firm ratio in Mexico [16] [17]. Simplification of costly procedures has a positive effect on firm size and formality decisions in Brazil [18]. Firms with high formalizing costs are better off registering for taxes, but those with lower costs are worse off and stay informal in Bolivia [19]. Financial incentives are not totally capable of inducing informal firms as a whole to register and become formal [20]. To the best of our knowledge, most of the studies belonging to this literature comprise empirical studies. In this study, we aim at contributing to the existent literature by providing a theoretical analysis of the optimum levels of these costly regulations in the labor market.

\section{The Model}

The basic assumptions of the model are given below:

1 ) There are two sectors: Formal sector $(F)$ and informal sector $(I)$. 
2) Total revenue of an informal firm $=q$. Total revenue of a formal firm $=\beta q$ where $\beta>1$ ( $\beta$ is the efficiency premium of being a formal firm).

3) Cost of workers in both sectors is $w$. It is determined out of the model and taken as fixed. Hence there is no wage determination side in the model. Labor supply is large enough that both sectors are able to match their labor demand at the fixed labor cost level of $w$ and we implicitly assume that wages in the informal sector is actually higher and formal sector has the insurance advantage. Labor costs are same due to the labor taxes in the formal sector.

4) Total cost for an informal firm $=w(w<q)$.

5) Risk of detection if you are in the informal sector $=d$. Profit of the informal firm if detected: 0 (for the period of detection).

6) Total cost for a formal firm $=w+c$ where $c$ represents the cost associated with occupational health and safety $(w+c<\beta q)$.

7) One period game: Formality decisions are taken by the firms and in the beginning of each period. Firms revise their informality/formality decisions given the current levels of $c$.

Labor in the informal economy is paid without a contract depending upon a verbal agreement and relationships between employee and employer remain hidden. Thus, it is reasonable to think that when an accident happens informal firms verbally agree with the worker or worker's legal successor for compensation. This level is generally lower than the level required by the law [21]. Considering this and other costs of formal firms associated with safety precautions, we add $c$ to the formal firm's cost function which represents its cost difference from an informal firm regarding occupational health and safety. That is, we normalize the costs of informal firms for occupational health and safety as zero and represent the additional cost of the formal firms in regard to health and safety with $c$.

When solving the model, the assumed probability of detection, in line with the literature, is taken to be a function of the share of informal firms in the market and the public interest in the issue of informality. As long as there are only a few informal firms in an industry, the regulatory authority's effort to detect informal firms in the industry is lower. Hence, an informal firm's probability of getting caught is low. However, if you are working in an industry with a larger informal sector, being an informal firm is no more an exception, it attracts attention of the government and the regulatory authority devotes its resources to that specific industry to decrease the size of the informality. This can be considered as the size effect. In addition, a bigger public interest in the issue of informality increases the likelihood of detection. First of all, people's displeasure from informality negatively affects their support for the government. Hence, in such a case, a vote maximizing government increases its efforts to detect informal firms in the industry. We should also note that when the public interest in the issue is bigger, people help the detection efforts of the government by their notifications to the authority etc. Hence the probability of detection $(d)$ is a function of the share of informal firms in the sector $\left(\eta=\frac{\text { number of firms in the informal sector }}{\text { total number of firms }}\right)$ and a parameter of public interest in the issue $(m)$.

$$
d=\eta * m
$$

\section{MODEL SOLUTION:}

Step 1:

If a firm works in the formal sector, with probability $d$ it will be detected and its total profit will be zero, and by $(1-d)$ probability the firm will have a profit of $(q-w)$.

A firm in the formal sector is assumed to be more efficient in regards to production, with its better institutional setting and its occupational health and safety precautions. Hence, its total revenue is going to be $\beta q$ and its profit is going to be $\beta q-w-c$.

A firm in the informal sector registers and works in the formal sector only if its expected profit in the formal sector is higher than its expected profit in the informal sector. We can solve for the equilibrium which makes the marginal firm indifferent between working in the formal or informal sector:

$$
\begin{gathered}
E\left(\pi_{I}\right)=E\left(\pi_{F}\right) \\
d(0)+(1-d)(q-w)=q \beta-w-c
\end{gathered}
$$

Given the levels of $q, \beta, w$ and $c$, firms are indifferent between working in the formal or informal sector only 
if the level of detection satisfies the following condition:

$$
d=\frac{q-q \beta+c}{q-w}
$$

Firms are indifferent between working in the formal and informal sector if the probability of detection is equal to the expression on the right hand side above.

From the assumptions above, we also know that the probability of detection is a function of the share of informal firms in the sector. Hence, given the levels of $q, \beta, w$ and $m$ by nature, the selection of $c$ by the government indirectly affects the size of the informal sector.

Step 2:

The government wants to maximize its profit function as well. The profit function of the government is based on the increase in welfare due to a safer occupational environment. ${ }^{6}$ We assume that a higher expenditure on safety increases the welfare of the society hence, government's profit by $c$ multiplied by a discount factor $\alpha$. $(0<\alpha<1)$.

The size of the discount factor in effect depends on two factors. The first factor is the value of people's lives and the second factor is the effectiveness of precautions that are taken to increase occupational health and safety. We should remember that these precautions decrease the risk in the working environment only to a certain extent. In addition, the parameter of public interest, shortened as $m$ before, is also based on a factor which is similar to the first determinant of $\alpha$ (economic value of life). Hence we connect $\alpha$ and $m$ through a parameter $b(0<$ $b<1)$ as $m=b \alpha$

Remembering that government can apply $c$ only to the formal sector, the share of which is equal to $1-\eta$, the government tries to maximize the following function:

$$
(1-\eta(c))(\alpha c)
$$

Proposition 1: Given $q, \beta, w, b$ and $\alpha$ the government chose an occupational safety level, effective cost of which to the firm (c) is equal to:

$$
\frac{b \alpha(q-w)+q \beta-q}{2}
$$

Proof: Due to its relation to the probability of detection, it was shown before that, for marginal firms to be indifferent between working in the formal or informal sector $=\frac{q-q \beta+c}{q-w}$, and $d=\eta m=\eta b \alpha$. Hence $(1-\eta)$ is equal to $1-\frac{d}{b \alpha}=1-\frac{q \beta-w-c}{\frac{q-w}{b \alpha}}$. That is, the government is trying to maximize the function $\left(1-\frac{q \beta-w-c}{\frac{q-w}{b \alpha}}\right)(\alpha c)$. Taking the derivative of this expression with respect to $c$ and setting it equal to 0 gives us the optimal value of $c$ as $\frac{b \alpha(q-w)-q+q \beta}{2}$ given that $q-w \neq 0, \alpha \neq 0$ and $b \neq 0$.

Q.E.D.

\section{Results}

According to the function derived by solving the model above, which determines the optimal value of $c$, the government is able to choose higher level of $c$ if the efficiency premium " $\beta$ " is much larger.(Derivative of the optimal value $c$, with respect to $\beta$ is greater than zero $(\beta>1)$. That is, firms choose to work in the formal sector due to high efficiency gains even if level of $c$ is high. In addition, if $\alpha$ is low in a country, meaning that a safer

\footnotetext{
${ }^{6}$ We implicitly assume that the sectors under investigation are low wage. Low amount of tax revenue from the wages in these sectors is actually used for workers' related expenditures and the government does not earn monetary profits from the taxes on the formal labor. Therefore, we exclude taxes on labor in the formal sector from the profit function of the government.
} 
occupational environment brings relatively lower wealth, governments do not choose high levels of obligatory occupational safety regulations, the cost of which is represented by $c$ in our model. (Derivative of the optimal value $c$, with respect to $\alpha$ is greater than zero $(0<\alpha<1)$. This low gain maybe due to the ineffectiveness of precautions or the lower value of people's lives in a country. Ineffectiveness of precautions plays a role, because even if there are costly regulations they may not increase the occupational safety to a considerable extent. For a better understanding of the issue of the value of people's life, we present selected indicators in Table 1 which

Table 1. Selected indicators for value of life as of 2008.

\begin{tabular}{|c|c|c|c|c|}
\hline COUNTRY & $\begin{array}{l}\text { Rates of fatal } \\
\text { injuries }\end{array}$ & $\begin{array}{l}\text { Life expectancy at } \\
\text { birth, total (years) }\end{array}$ & $\begin{array}{l}\text { Health expenditure, } \\
\text { total (\% of GDP) }\end{array}$ & $\begin{array}{l}\text { Health expenditure, public (\% of } \\
\text { government expenditure) }\end{array}$ \\
\hline Japan & 0.0 & 82.59 & 8.61 & 18.61 \\
\hline Saint Vincent and the Grenadines & 0.0 & 71.88 & 4.70 & 13.19 \\
\hline Sri Lanka & 0.0 & 73.62 & 3.41 & 6.87 \\
\hline Cuba & 0.0 & 78.34 & 10.79 & 13.18 \\
\hline Luxembourg & 0.0 & 80.54 & 7.34 & 16.59 \\
\hline Korea, Republic of & 0.1 & 79.83 & 6.64 & 11.88 \\
\hline Azerbaijan & 0.1 & 70.06 & 4.37 & 3.07 \\
\hline Mauritius & 1.0 & 72.57 & 4.60 & 7.95 \\
\hline Switzerland & 1.1 & 81.99 & 10.29 & 20.89 \\
\hline Sweden & 1.5 & 81.10 & 9.23 & 14.54 \\
\hline Malta & 1.9 & 79.64 & 8.18 & 12.25 \\
\hline France & 2.0 & 81.21 & 10.91 & 15.83 \\
\hline Norway & 2.0 & 80.59 & 8.55 & 18.15 \\
\hline Germany & 2.0 & 79.74 & 10.70 & 18.56 \\
\hline Australia & 2.1 & 81.40 & 8.78 & 16.86 \\
\hline Ireland & 2.5 & 80.10 & 8.99 & 15.85 \\
\hline Canada & 2.7 & 80.54 & 9.99 & 17.95 \\
\hline Singapore & 2.8 & 80.79 & 3.90 & 8.57 \\
\hline Hungary & 3.0 & 73.70 & 7.46 & 10.16 \\
\hline Estonia & 3.2 & 73.77 & 6.06 & 11.88 \\
\hline Spain & 3.3 & 81.18 & 8.93 & 15.73 \\
\hline United States & 3.7 & 77.94 & 16.10 & 18.96 \\
\hline Czech Republic & 3.8 & 76.98 & 6.82 & 13.68 \\
\hline Cyprus & 3.9 & 79.00 & 6.89 & 6.77 \\
\hline Italy & 4.0 & 81.49 & 8.89 & 14.44 \\
\hline Austria & 4.1 & 80.43 & 10.49 & 16.23 \\
\hline Slovakia & 4.2 & 74.70 & 8.02 & 15.57 \\
\hline Poland & 4.5 & 75.54 & 6.89 & 11.43 \\
\hline Bahrain & 5.0 & 75.98 & 4.10 & 9.78 \\
\hline Kyrgyzstan & 5.0 & 68.45 & 6.07 & 13.06 \\
\hline Belarus & 5.1 & 70.46 & 5.95 & 7.87 \\
\hline Croatia & 5.2 & 75.91 & 7.80 & 15.26 \\
\hline Moldova, Republic of & 5.3 & 68.23 & 11.41 & 12.97 \\
\hline Bulgaria & 6.4 & 72.96 & 6.97 & 10.63 \\
\hline Lithuania & 6.6 & 71.81 & 6.61 & 12.62 \\
\hline Ukraine & 8.0 & 68.25 & 6.63 & 11.73 \\
\hline Kazakhstan & 8.2 & 67.02 & 3.65 & 8.32 \\
\hline Myanmar & 8.6 & 64.19 & 2.03 & 1.24 \\
\hline Romania & 9.0 & 72.57 & 5.44 & 11.34 \\
\hline Costa Rica & 9.1 & 78.90 & 9.01 & 26.09 \\
\hline Turkey & 9.8 & 73.53 & 6.07 & 12.21 \\
\hline Mexico & 10.0 & 76.23 & 5.84 & 14.96 \\
\hline Russian Federation & 10.9 & 67.85 & 6.17 & 10.08 \\
\hline Dominican Republic & 17.9 & 72.35 & 4.49 & 8.47 \\
\hline
\end{tabular}

Source: ILO \& Worldbank 
can be regarded as proxies for the value of life. Table 1 reveals that in selected industrialized countries rates of fatal injuries are lower, life expectancy is relatively higher, and health and education expenditures are higher, whereas in selected Asian, South American and African developing countries, these figures are relatively higher and lower respectively. This leads us to conclude that the economic value of life is higher in developed countries then in developing ones.

Given the lower economic value of life in developing countries, the lower regulation level is expected according to our model through the lower value of the parameter " $\alpha$ ". The occupational health and safety regulation level is actually relatively lower in developing countries and as a result workplace accidents and death rates are higher [22].

\section{Conclusions}

In this study, we theoretically investigate the determination of optimal levels of occupational health and safety in an environment where formal and informal sectors coexist.

The findings of the constructed model imply that governments, especially in developing countries with large informal sectors, should consider the consequences of their regulatory decisions on the informal-formal choice of firms.

According to the constructed theoretical model, we find that firms operating in industries with high possible efficiency gains when they work formally, choose to operate in the formal sector even they face high occupational health and safety costs.

In addition, countries which place a higher value on human life tend to end up with higher optimal levels of occupational health and safety. This result is actually supported by data which show higher occupational safety and lower resulting accident rates in developed countries, which have a higher regard for human life. The findings of the model can be extended to other regulatory frameworks as well (as minimum wage determination) where informality exists as an outside option. An empirical study of the findings of this paper is of interest for future research.

\section{References}

[1] Worldbank (2000) Informal Labor Markets in Transition Economies. Concept of Informal Sector. http://lnweb90.worldbank.org/eca/eca.nsf/Sectors/ECSPE/2E4EDE543787A0C085256A940073F4E4?OpenDocument

[2] The Informal Economy: Fact Finding Study. Department for Infrastructure and Economic Cooperation.

[3] Kay, D.D. (2011) The Relationship between Formal and Informal Employment in South Africa. Unpublished Master's Thesis, Urbana, Illinois.

[4] Lordoglu, K. and Ozar, S. (1998) Enformel Sektörve Sosyal Güvenlik: Sorunlarve Perspektifler, FES, İstanbul.

[5] Schaefer, K. (2002) Capacity Utilization, Income Distribution, and the Urban Informal Sector: An Open Economy Model. PERI Work, Amherst, MA, Paper No. 35.

[6] Portes, A. and Hoffman, K. (2003) Latin American Class Structures: Their Composition and Change during the Neoliberal Era. Latin American Research Review, 38, 41-82. http://dx.doi.org/10.1353/lar.2003.0011

[7] Worldbank (2000) Informal Labor Markets in Transition Economies. Labor Market and Tax Regulations. http://nweb90.worldbank.org/eca/eca.nsf/Sectors/ECSPE/84BCF033AC636F0885256A940073F4E7?OpenDocument

[8] Valentina, F. (1999) Improvement of Working Conditions and Environment in the Informal Sector through Safety and Health Measures.

http://www.ilo.int/wcmsp5/groups/public/---ed_protect/---protrav/---safework/documents/publication/wcms_110306.p $\underline{\mathrm{df}}$

[9] Blades, D., Ferreira, F. and Lugo, M. (2011) The İnformal Economy in Developing Countries: An İntroduction. Review of Income and Wealth, 57, 1-7. http://dx.doi.org/10.1111/j.1475-4991.2011.00457.x

[10] La Porta, R. and Shleifer, A. (2014) Informality and Development. Journal of Economic Perspectives, 28, 109-126. http://dx.doi.org/10.1257/jep.28.3.109

[11] Taymaz, E. (2009) Informality and Productivity: Productivity Differentials between Formal and Informal Firms in Turkey. ERC Working Papers.

[12] Dabla, N.E., Gradstein, M. and Inchauste, G. (2005) What Causes Firms to Hide Output? The Determinants of Informality, IMF Working Paper No. 05/160, IMF, Washington DC.

[13] Peña, X. (2013) The Formal and İnformal Sectors in Colombia: Country Case Study on Labour Market Segmentation. 
Employment Working Paper No. 146, ILO, Geneva.

[14] McPherson, M.A. and Liedholm, C. (1996) Determinants of Small and Micro Enterprise Registration: Results from Surveys in Niger and Swaziland. World Development, 24, 481-486. http://dx.doi.org/10.1016/0305-750X(95)00147-5

[15] Djankov, S., La Porta, R., Lopez de Silanes, F. and Shleifer, A. (2002) The Regulation of Entry. Quarterly Journal of Economics, 117, 1-37. http://dx.doi.org/10.1162/003355302753399436

[16] Bruhn, M. (2011) License to Sell: The Effect of Business Registration Reform on Entrepreneurial Activity in Mexico. Review of Economics and Statistics, 93, 382-386. http://dx.doi.org/10.1162/REST_a_00059

[17] Kaplan, D., Piedra, E. and Seira E.(2011) Entry Regulation and Business Start-Ups: Evidence from Mexico. Journal of Public Economics, 95, 1501-1515. http://dx.doi.org/10.1016/j.jpubeco.2011.03.007

[18] Fajnzylber, P., Maloney, W.F. and Montes Rohas, G.V. (2011) Does Formality Improve Micro-Firm Performance? Quasi-Experimental Evidence from the Brazilian SIMPLES Program. Journal of Development Economics, 94, 262-276. http://dx.doi.org/10.1016/j.jdeveco.2010.01.009

[19] McKenzie, D. and Sakho, Y.S. (2010) Does it Pay for Firms to Register for Taxes? The Impact of Formality on Firm Profitability. Journal of Development Economics, 91, 15-24. http://dx.doi.org/10.1016/j.jdeveco.2009.02.003

[20] Del Mel., S., McKenzie, D. and Woodruff, C. (2012) The Demand for, and Consequences of Formalization among Informal Firms in Sri Lanka. Working Paper, World Bank.

[21] Yogesh, A. (1999) Poverty in Transition and Transition in Poverty: Recent Developments in Hungary, Bulgaria, Romania, Georgia Russia and Mongolia.

[22] Birn, A.E., Pillay, Y., Holtz, T.H. and Basch, P.F. (2009) Textbook of İnternational Health: Global Health in a Dynamic World. Oxford University Press, New York. 